\title{
Bible and Gun: Militarism in Jerusalem's Holy Places
}

Wendy Pullan

University of Cambridge

Abstract:

Violence is a regular occurrence at many of Jerusalem's holy sites. Ongoing civilian clashes play a role, but official modes of control through the Israeli army (IDF) and Border Police as well as more informal private security operations are often involved. Such militarisation may keep violent upheavals in check, but it is carried out within the framework of a long and harsh occupation. The two sites considered here - the Western Wall in the Old City and Rachel's Tomb on the border of Jerusalem and Bethlehem - each have a history of war and are fixtures of the occupation. This study explores the mechanisms that embed religious and militaristic meanings at each site. In doing so, certain questions are addressed: firstly, how are the sites being constructed and used as popular and dramatic settings for certain constituents to promote religious militarism/militarised religion in Jerusalem? In which ways do these characteristics act to intertwine with the religious and militaristic aspects of the sites, making them more extreme but also, in some circles, more attractive? And finally, how do these sites contribute to the character of Jerusalem, both in their own construction and image but also in the roles they play within the wider urban topography? 
In a study of the role of religion in the Israel Defence Forces (IDF) today, Stuart A Cohen (2000, p. 254) relates a homily from the third century CE. In this teaching, the scroll and the sword are presented as having come 'down from Heaven tied together'. God advises the Israelites 'if you observe the torah... which is written in the one, you will be saved from the other; if not, you will be smitten by it'. Cohen then goes on to say that in modern Zionist thinking, the sword and the scroll have become twinned rather than mutually exclusive; both are deemed necessary in order to serve the country (p. 254-55). Yet since the first Palestinian Intifada (uprising) in 1987 and the Oslo Accords of the early 1990s, ${ }^{1}$ the rise of religious nationalism in Israel has been dramatic in the face of relinquishing land for peace. ${ }^{2}$ This is especially evident in the influence of right-wing, and often extremist, Jewish settler movements on and within the Israeli government and military; to good extent religious nationalism has moved from the fringes of society to a central position (Zertal and Eldar, 2007; Gorenberg, 2000; Feige, 2009; Inbari 2009).

It is once again possible to re-assess the sword and scroll relationship to suggest that rather than being equal to or led by armed struggle, religion has becoming a primary driving force in Israeli militarism. In reference to the dominant settler movements, Feige explains 'the fusion of the political and the religious' as a 'religious dictim in the eyes of the believers' (Feige, 2009, p. 33). In broader terms, Kimmerling explains the nation's shift from a 'national

${ }^{1}$ The period of negotiations between Israel and the PLO in the first half of the 1990 s is often referred to as 'Oslo'. ${ }^{2}$ Kimmerling (1999, p. 342) explains religious nationalism as 'arriving at Zionism from a religious starting point'. 
security religion' to a 'national religious culture' favouring the creation and maintenance of a Greater Israel as derived from biblical ideals (1993, p. 217). ${ }^{3}$ It would be wrong to belittle Israel's emphasis upon security, which still dominates most political and military thinking; as an over-riding concept, and a threat, it is regularly used to enlist the support of secular Jews and alienate Palestinians. But Kimmerling's emphasis upon a new aggressiveness in the name of religion shows the concept to have altered to mean the security of the Jewish nation and the biblical Land of Israel (Eretz Yisrael). This thinking dominates not just the fighting of wars, but it carries with it an ideology that permeates the practice of everyday life. As will be argued here, it dominates the form and meaning of major Jewish holy places within the urban character and spatial structure of Jerusalem.

To fair extent, and in religious circles, national religious Jews have taken the upper hand from the ultra-orthodox groups, or haredim. The differences between the two are not always distinct, but it is possible to say that generally the latter believe in redemption realised in God's own time and unaffected by human interference, whereas for national religious adherents, all of the Land of Israel is considered God-given, carrying an obligation for Jews to redeem it by human hands. This may be accomplished by violence if necessary, regardless of who lives there or has previous claims on the land or ownership of property. The difference between the two groups is well summarised by the criticism of national religious groups by a haredi rabbi: 'instead of adapting their ideology to Judaism, they wish to adapt Judaism to their

${ }^{3}$ Kimmerling (1993, p. 208) believes that the place of the IDF and Israel's security always had a sacred status in a secular sense, but this has changed to a clearly religious conviction. 
ideology' (Sela, 2007; see also: Kimmerling, 1999, pp.342-43). Along with private security and vigilante groups, the extreme factions of national religious Judaism advocate the use of state military force to secure and redeem the Land (Cohen 2007, p. 5).

As Jewish religion and nationalism have become more interdependent, Jerusalem has become central to national religious efforts and the ideology Mayer, 2008, p. 240). Within the Land, Jerusalem remains the Holy City; it was the site of the Jewish Temple, now destroyed. The major remaining physical fragment of the Second (Herod's) Temple, the Western Wall (Kotel ha-Maaravi), has become Judaism's most sacred place. Other sites in Palestinian East Jerusalem have been revived or reinvented as holy places, sometimes with little historical or archaeological, basis, and usually to the detriment of the Palestinian inhabitants on or near the sites (Pullan et al, 2013, chs. 2, 7; Emek Shaveh)). The 'City of David' in Palestinian Silwan is the largest and most prominent, and has been fabricated as a major tourist site (Pullan et al, 2013, ch. 4); the Muslim Quarter of the Old City is becoming dotted with yeshivas, synagogues and other places of prayer (Pullan et al, 2013, ch. 7). Several ancient tombs have been venerated traditionally by the three monotheistic faiths but taken over exclusively by Jews, having experienced a revival in interest by both haredi and settler groups. Rachel's Tomb is one of the most significant of these. Located in Palestinian Jerusalem, the tombs are heavily contested and provide focal points for the settlers to appropriate adjacent areas of Palestinian property as settlements. 
Violence is a regular occurrence at many of Jerusalem's religious sites. Ongoing civilian clashes play a role, but official modes of control through the IDF and Border Police as well as more informal private security operations and informal militias of the settlers are often involved. Such militarisation may keep violent upheavals in check, but as it is within the framework of a long and harsh occupation, violence forms a subtext that is close to the surface and constantly at the point of erupting. The two sites to be considered in this article - the Western Wall in the Old City and Rachel's Tomb at Jerusalem's southern extreme on the edge of Bethlehem - each have a history of war and are fixtures in the occupation (figure 1). This article will explore how the current religious and militaristic meanings of each site are embedded within their physical construction and location. The former is undisputedly Judaism's holiest shrine and the latter has been described as the religion's second or third holiest place (the discrepancy seems to come from selfappointed guardians). Both sites are dependent upon a combination of scriptural narrative and modern historical interpretations for their present content and esteem. Yet, today in Jerusalem, the two sites have different constituents: the Western Wall is central to the city and the nation and figures in the imagination of the secular population, whereas Rachel's Tomb has come to represent a more extreme form of religious radicalism attractive to its own dedicated followers but few others. Their geographical locations in Jerusalem reflect their status.

I shall restrict my study to the Jewish structuring and controlling of the two sites, but always shadowing the Jewish occupation is the legacy of Palestinian dispossession. It is both the cause for and the real victim of the conditions I 
investigate and at both sites, the Palestinian city is physically adjacent and visible. But I also suggest that the measures taken at the Jewish sites go beyond the need for national security or controlling the Palestinians, and instead take on a life of their own, promoting a religious and nationalistic image of communal violence that supports the twin goals of retaining the land and hastening messianic redemption. Several key issues repeatedly arise and will be explored: firstly, how are the sites being constructed and used as popular and dramatic settings for certain constituents to promote religious militarism/militarised religion in Jerusalem? How do these characteristics act to intertwine with the religious and militaristic aspects of the sites, making them more extreme but also, in some circles, more attractive? And finally, how do these sites contribute to the character of Jerusalem, both in their own construction and image but also in the roles they play within the wider urban topography?

This article has developed out of extensive research on the urban aspects of Jerusalem and how they relate to the wider Israel-Palestine conflict. ${ }^{4}$ The situation is complex and the findings presented here are intended to illustrate aspects of this confusing and often contradictory city although not necessarily to clarify it. Despite the various ideological factions that attempt to dominate it, Jerusalem is a city that is characterised by ambivalence. My research has entailed the monitoring of the two primary sites over time, and although my

"The research for this article forms part of the ESRC Large Grant project, 'Conflict in Cities and the Contested State', undertaken 2007-13 (RES-060-250015 ) and the ESRC-funded 'Conflict in Cities: Architecture and Urban Order in Divided Jerusalem', 2005-7 (RES-228-25-0056). Historical research on the Western Wall and Rachel's Tomb was begun in the early 1990s. I am grateful to Lefkos Kyriacou for drawing the maps for this article and for comments by the anonymous reviewers. 
text refers primarily to their current attributes, my insights have been gleaned, at least in part, by many return visits. ${ }^{5}$ My approach is phenomenological; thus description, where place is key to particular understandings, may be laborious to read but essential nonetheless. Rachel's Tomb and the Western Wall have been observed and documented through visual research and architectural site work as well as the more standard use of interviews and archival investigation.

\section{Violence, militarism, militarisation and security}

In the sites I consider here, militarism may be regarded as a value that contributes to particular controls in spatial structures and practices, and that incorporates exclusivity beyond their articulation as holy places. In doing so, it is regularly seen to conflict with civilian roles and expectations, may project violence, actual or feared, onto the sites, or may become sufficiently absorbed in the holy places to emerge as a major feature of them. As security is put into the hands of private firms and informal settler groups, and the Israeli authorities turn a blind eye, agree to, or even pay for these services (Benn, 2009; Haaretz Editorial, 2013), there is a fluid and often unclear relationship between official and informal policing and this lends a sense of uncertainty to the sites. A recent study of policing in Palestinian Jerusalem points out that 'policing priorities and objectives in East Jerusalem are directed primarily towards the maintenance of public order rather than law enforcement' (Dumper, 2013, p. 1260). These shifting conditions must be seen against a system where the absence of written documents is notable (Cohen 2007, p.6; Eggen Røislien, 2013, p. 214) and obscure and ad hoc procedures appear to

${ }^{5}$ In this article, my references to site visits note only my most recent encounters with these holy places. 
intentionally confuse (Pullan, 2013b; Weizman, 2007, p.5). The result is long term uncertainty in everyday Palestinian life and the hardening of the occupation.

The linking of militarism and violence may seem obvious but raises certain questions. The use of the word 'violence' as something common within a society may be rejected although calling it militarised is acceptable. Catherine Lutz points out that in the USA talk of the 'merits of violence' is not tolerated and the image of 'soldiers as warrior-killers' is obscured; nonetheless, war preparation is extolled (2002, p. 725). It is sometimes argued that inside a militarised culture, control is sufficiently widespread and severe that active violence is lessened; certainly it is difficult to know if there would be greater incidence of day-to-day violence in Jerusalem without heavy policing. Whilst it is not my intention to investigate the possibilities for reducing violence in Jerusalem, I am interested in how the combination of messianic religious practice and militarisation combine at certain physical locations to foster certain meanings that are recognised as violent. This may be so even if the hostilities were in the past or are held at bay. I ask what are some of the mechanisms in the sites that convey violence and mix it so effectively with religion.

With periodic wars, ongoing occupation and an armed forces of well over half a million, it is not difficult to regard Israel as a militarised society (Cohen, 2008, p.1). ${ }^{6}$ Much has been said about Israel's obligatory conscription of all

- Out of a total population in Israel of 7,400,000, regular armed forces personnel are 176,500, reserves: 445,000, border police: 7,650 (Institute of National Security Studies, 2011). 
Jewish males and females, and the 'us and them' feeling engendered in an army that uses ethnicity to define its members (among others, Eggen Røislien, 2013, pp.220-24, passim).? Opinions are divergent in considering whether Israel is a militaristic society, that is, whether militarism is constitutive of its culture and society (Cohen, 2008, pp.5-13; Ben-Eliezer, 1998, pp.7-15). Kimmerling represents Israeli militarism as a 'latent state of mind' (1993, p.200); other approaches stress the diversity of the army and Israeli society (Lomsky Feder and Ben-Ari, 1999), and some a more nuanced relationship between formal and informal procedures (Sheffer and Barak, 2010). Various scholars have characterised and defined these terms, but Lutz's terminology on the American military forces and Kimmerling on the IDF make useful counterpoints. With respect to militarisation, Lutz characterises it as a process 'involving a shift in general societal beliefs and values in ways necessary to legitimate the use of force, the organization of large standing armies and their leaders, and the higher taxes or tribute used to pay for them' (2002, p.723). She differentiates militarisation from militarism where the latter identifies 'a society's emphasis on martial values (p. 725)'. This echoes Kimmerling's cultural militarism 'when the armed forces become essential to the social experience and collective identity [of a nation]' (1993, p. 202). But Lutz also suggests militarism is where 'warlike values have an independent ability to drive social change' (2002, p. 725). This point can be taken with Kimmerling's idea that 'the main expression [of militarism] is a latent state-of-mind' [my italics] (1993, p. 206). The separation of militarism from straightforward military practice, so that it becomes embedded in the larger culture to become

' Most Arabs do not serve in the IDF; many haredim are regularly discharged from service; youth from a national religious background serve and often lead. 
a latent characteristic, is an important phenomenon that reflects how militarism can be absorbed into the urban fabric of Jerusalem through its holy places. Whilst militarisation is consciously used by national religious groups to facilitate their aims, the city and a broader spectrum of its citizens may absorb militarism through more insidious means.

Security in Israel is so ingrained as to be a latent factor of most aspects of life. It is not just a matter of military preparedness but a fact of civilian experience. Security has been criticised for rendering civil society powerless in the face of its hegemony (Barak and Sheffer, 2010, p.19), where "'national security" resonates much better than "civil liberties"' (Benn, 2013). In the Israeli planning of Jerusalem after the 1967 war, security was cited as the main driving force, yet in practice, it became an excuse for separating Israelis and Palestinians and for managing the city to suit Israeli needs only (Pullan, 2013a). The Jewish holy places in East Jerusalem, having become foreign enclaves in alien territory, are physically bounded and particularly susceptible to stringent security measures; these often develop as a symbiotic part of the religious site itself. In fact, it is possible to say that visible security enforcement is relied upon to enhance the struggle for and value of some holy places. Under certain circumstances security practices are 'put on show', and at some holy sites in Jerusalem the combination of religious ritual and military spectacle can be impressive. With respect to security infrastructure, it is important to note that not all is visible, and a tension between what is seen and unseen is in some ways analogous to the prominent and the latent of militarism. 
Street violence in Jerusalem - both civilian and military - has a pattern of visibility that includes intense and sporadic outbreaks as well as a persistently high level of volatility where hostilities percolate through the urban everyday but are often unseen. This underlying violence often makes the visible shows of security all the more desirable to Israelis and threatening to Palestinians. Certain key sites, like the Western Wall, become authoritative through a combination of religious ritual and military procedure. Security is cited as the reason for the latter which itself is invoked in order to ensure the former. Spatial infrastructures are regularly reinforced and extended, both to make them increasingly secure and to appear to be so. Such treatment reflects the potential violence that is widely believed to be inherent in the religiosity of the site (Hassner, 2009, pp. 2-4, 31-34, passim).

\section{The Western Wall as military spectacle}

Since 1967 when Israel conquered Jordanian Jerusalem and gained for itself the Western Wall, it has become increasingly common to hold swearing-in ceremonies (tekes hashba'ah) for new soldiers joining certain units of the Israel Defence Forces. ${ }^{s}$ Sites that resonate with the national aspirations of the Jewish people are favoured for such oaths of allegiance, but the Western Wall is primarily a holy place and its use questions the extent to which national institutions might be encroaching on religious sites, or vice versa (Horowitz and Lissak, 1989, p.140). Particularly the paratroopers brigade is associated

'The website of the Western Wall Heritage Foundation reported a recent increase from 15 ceremonies in 2008 to 30 in 2012.

- It is well accepted that there is a strong religious dimension to the IDF. National sites for swearing-in ceremonies include the locations of major battles in 1967 such as Latroun and Ammunition Hill, and Masada, an ancient 
with the Wall, having 'liberated' it in the 1967 War; but the site has become allied more generally with the IDF, and the image of soldiers there is iconic in Israel (Semmerling, 2004, pp.37-42). In replacing what was perceived as oldfashioned religious observance, fit young troops represent the fighting force required to maintain a Jewish state. On the other hand, national ceremonies at the Wall have become more religious over time: in the swearing-in ceremonies, sermons, prayers and spiritual songs augment what once was simple and 'war-oriented' (Press, 2010, pp.5-6), female soldier choirs are no longer permitted to sing (Saragusti, 2013), and male and female soldiers who normally serve together are separated for the purpose of induction (Nachshoni, 2013). These changes may be equated with the dominance of the national-religious factions and to some extent their integration with more traditional groups (Press, 2010); at the same time, the ultra-orthodox institutions like the Chief Rabbi's Office remain powerful. Secular Israelis tend not to be involved, yet resist the increased religiosity at what they see as primarily a national site.

The swearing-in ceremony is a festive occasion, attended by family and friends who enjoy it as a day-out in Jerusalem and a chance to picnic in the Western Wall Plaza; however, the main purpose of their visit is to witness the new soldiers in their first formal role. ${ }^{10}$ Unsurprisingly state and military insignias and flags are prominently displayed; religious symbols are already

fortified mountaintop south of Jerusalem, the site of a mass suicide of Jewish rebels against the Roman army in CE73 (Ben-Yehuda, 1995, ch.7).

${ }^{10}$ The ceremonies vary somewhat according to the traditions of the particular unit of the IDF. My observations of the families and anonymous interviews with them are taken from the dress rehearsal and swearing-in ceremony of the anti-aircraft training base of the IDF Air Force, (Conflict in Cities, interviews, 2011). 
in place. Many of the events are held at night, and with floodlights, bunting, marching, drum-rolls, and the monumentality of the Wall as backdrop, it is a dramatic spectacle (figure 2). Perhaps the most potent symbol of the union of religion and military is the presentation of each soldier with a Hebrew Bible (tanakh) and a gun. The procedures vary slightly between different IDF units; the paratroopers insert the Bible under the recruit's shirt next to his heart and then present the weapon. At the Air Force's anti-aircraft training ceremony, the Bibles are placed on wheeled trolleys covered with embroidered velvet, similar to the sort often crafted to cover Torah scrolls in a synagogue; the guns are propped up in rows along the side (figure 3).

The ritual enlists each individual to join the collective and together they symbolise the soldier's new bond to the mother country and its fighting force; both are not simply Israeli but Jewish (Eggen Røislien, 2013, p.220). It is a complicated relationship, well beyond the scope of this article, but it is worth noting that recently cracks in this model of allegiance have appeared where some soldiers coming from national-religious backgrounds resist the perceived role of the army in maintaining national consensus; they claim that their primary 'loyalty is to God' (Press, 2010). The juxtaposition of the two fundamentals of faith and military has, to good extent, been absorbed into Israeli public life. At a swearing-in ceremony, the mother of a soldier in one self-declared secular family commented that that the gun will be more useful to her son than the Bible, but she sees no problem with the combination (Conflict in Cities interviews, 2011). Weapons are not unusual in Israeli public places and are present at the Wall in other events: participants in bar mitzvah 
ceremonies can be seen to wrap the leather bindings of phylacteries on one arm and a gun strap on the other (figure 4).

Activity at the Western Wall follows the cycles of the Jewish religious year: organised prayer takes place each Sabbath, on religious holidays and for bar mitzvahs; but at any time of the day or night worshippers may be found there for more spontaneous individual prayer. For Jewish religious life, it is the main focus - for the city, for the country, and for the diaspora. At the same time, this holy place is controversial and contested, not only for having been conquered in war, but also because, as well as a remaining wall of the Second Temple, it is part of the retaining wall of the Islamic compound known as alHaram al-Sharif. For many years before 1967, Jewish worship took place along a narrow passage in front of the Wall. Within days after the 1967 War, the Israeli authorities demolished the Palestinian Magharib Quarter that stood in front of the Wall in order to create the large open plaza that stands there today and accommodates large numbers of people who flock there, including the pious, tourists, and the merely curious. Jewish religious institutions line the Western Wall Plaza and it has been developed to become not only a religious compound but an official manifestation of State. Hence, two major compounds - Jewish and Islamic - are poised in opposition, each on each other's ruins, tightly juxtaposed and entwined, in the centre of Jerusalem's Old City.

From many places in the Western Wall Plaza, the domes of the Muslim Dome of the Rock and al-Aqsa Mosque are easily visible on the Haram. This is particularly true in the theatrical setting of the IDF's swearing-in ceremony: 
the focus of Israeli belligerence and fear stands just beyond the Wall (figure 2). This borderland has seen many violent clashes: the excavation of a tunnel resulted in riots and many deaths; proposed Israeli renovations to the ramp to the Muslim al-Buraq Gate caused heavy unrest; Ariel Sharon's visit to the Haram via this gate in 2000 set off the Second Intifada, to name only a few. Many of these events took places at the juncture between religious belief and national security. The site is stoked with a hostile past; it is one of the most contested and potentially ferocious places in the world. For young recruits, the spatial setting dramatically and emotionally reinforces what they already know: the national security discourse is being ratcheted upwards by religious fervour. This is palpably evident as they are formally inducted into that particular violent world.

\section{The fortress Tomb of Rachel}

If the Bible and gun ceremonies at the Western Wall capitalise on longembedded violence right at Jerusalem's centre, militarism has also become entrenched at a location on Jerusalem's periphery. For many years, Rachel's Tomb (Hebrew: Kever Rahel; Arabic: Qubeh Rahil, also known as Bilal ibn Rabah Mosque) was a sleepy Ottoman structure on the road between Jerusalem and Bethlehem, traditionally believed by the three monotheistic religions to be the burial site of the biblical matriarch Rachel (Strickert, 2007; Selwyn, 2009). Through most of its history, members of these faiths cooperated in the use of the site (Selwyn, 2009, p.43), although Cust (1980, pp.46-48) describes some friction during the British Mandate when Jews held the keys to the shrine and the structure was surrounded by a Muslim cemetery. Following biblical passages that describe Rachel's dedication to her 
children and her death in childbirth on the road," the tomb has been a favourite place of veneration by women.

Since 1967 the structure has been in Jewish hands and has suffered periodic episodes of heavy violence, especially during the two intifadas (Hassner, 2009, pp.115-16; Selwyn 2009, p.43). In 2005, it was declared unilaterally by Israel as part of Jerusalem, and today the site stands in a no-man's land between Jerusalem and Bethlehem, not just on but in the border between Israel and Palestine (figures 1, 5). In legal terms its location is heavily contested; it was to have been returned to Palestine under the Oslo agreements but in 1995, under pressure from settlers and religious groups, Israel decided to retain it. Since then this important Jewish holy place has been made into a high-profile national religious shrine, referred to by its devotees as either the second or third holiest place in Judaism. The uncertainty about its status stems from different competing interest groups, but the ranking also indicates a recently revived and politically motivated place in the Jewish pantheon. The site's religious status and political value have resulted in extraordinary defensive measures being adopted. Today, the Tomb is completely enveloped by the concrete separation barrier" making it available to Israeli Jews and tourists coming from Jerusalem in approved vehicles, but inaccessible to Palestinians. It has become a military zone, literally an urban fortress (figure 6).

\footnotetext{
"So Rachel died and was buried on the way to Ephrath (that is, Bethlehem), and Jacob set up a pillar upon her grave; it is the pillar of Rachel's tomb, which is there to this day (Genesis 35.19-20).

${ }_{12}$ The wall, built by Israel on Palestinian land to enclose its own settlements and segregate much of the Palestinian population from Israel. For the sake of clarity, I capitalise the Western Wall and not the separation barrier or wall.
} 
The extreme conditions of Rachel's Tomb require further description. The sense of isolation, fortification and religiosity begins in the centre of Jerusalem. A city bus, advertised since 2009 as no longer needing bullet-proof glass, makes its way from the Central Bus Station and haredi neighbourhoods. The vehicle is filled mostly with religious women, heads covered, making good use of the journey to whisper psalms in the silence that pervades the inside of the vehicle; new passengers are invited to buy printed copies of the prayers. ${ }^{13}$ An Israeli soldier checks passports before the bus enters into a corridor within the separation barrier, leading to the fortified enclosure. This walled umbilical cord is all that connects the shrine to Israel; otherwise the Tomb is embedded in the edge of a sprawling Bethlehem, enveloped in the separation barrier, and adjacent to Palestinian Aida Refugee Camp on the other side of the wall (figures 5, 7). Most of the enclosed site is open, named 'Our Mother Rachel Square', apparently an attempt to normalise it and bring it into the urban domain. The tiny tomb structure is hidden behind a long stone portico with guard towers on either end. The dominant impression is of a modern-day bastion, or a high-security prison, so grimly and so thoroughly is it severed from it surroundings. Steel security gates, barbed wire, watchtowers, police barriers, floodlights and surveillance cameras punctuate the wall. Armed military personnel are well in evidence and there is a strong sense of a joint endeavour between the faithful and the military, a relationship supported by the Tomb websites (Rachel's Tomb Institute; Rachel's Tomb Committee). Army insignias are proudly displayed on the sites.

\footnotetext{
${ }^{13}$ Most recently visited 6.1.13.
} 
The passengers from the bus stream into the complex to pray (figure 8). The tomb room is divided diagonally by a wall that separates male and female worshippers. The tomb structure itself is covered in embroidered velvet (like the Bible and gun trolley at the Western Wall); on one side is an embroidered image of the tomb and on the other the Temple of Jerusalem, a clear reference between the outlying site and its larger, more mainstream counterpart in the centre of Jerusalem (figure 9). Although festivals are celebrated and regular religious lessons take place, connected to the settler-established yeshiva on the site, much of the prayer at the Tomb is personal. Individual supplication and lamentation takes place in the shadow of Rachel who, as the worshippers believe, died on her journey in a place undefined and belonging to no one. Its new location within the confines of the separation barrier continue to relegate it to no-place between two embattled cities; yet this no-place is also highly coveted by each embattled nation. For Palestinians the site is on the edge of a refugee camp, part of a Bethlehem suburb that no longer exists (Selwyn, 2009, pp. 44-45); for many Israelis, it is beyond the pale, in dangerous or forbidden territory, and not part of the Jerusalem constellation. It is a fortress shrine in a frontier zone.

Various Jewish groups use and exert control on this site. Haredim, especially mizrahim (orthodox Jews of eastern or oriental origin), traditionally make pilgrimage to the Tomb, as is typical of many holy tombs in Israel. The more militant settlers pray there, but also see it as an inroad into the Palestinian territories of Bethlehem. Moreover, in turning to biblical tradition for legitimisation, religious-nationalist camps are happy to exploit Rachel as 
Mother of the Hebrew nation and modern day Israel (Feige, 2009, pp.222-24). ${ }^{14}$

Selwyn's observation that the settlers and mizrahim are brought together at the Tomb remains true (2009, p.49), yet, as at the Western Wall, the settlers are in the ascendant, and able to capitalise on the inherent religious meanings of Rachel's burial place along with the increased militarisation that arises from their incursions. Newman (2012) describes the crowds who venerate the Tomb on the anniversary of Rachel's death simply as ultra-orthodox and points out that this population no longer is considered moderate with respect to the Palestinians and the occupied territories. The sense of an enemy at the gates of Jerusalem is a powerful one for many of the devotees of Rachel's Tomb. And as at the Western Wall, the view to Palestine - in this case houses and a mosque over the defensive wall - shows it to them clearly (figure 7).

In Our Mother Rachel Square, a garden with a mural of a small domed tomb, itself in a pastoral landscape, depicts the structure as it was under the Ottomans (figure 10). The image is used widely, on models, children's toys, charity boxes, even tombstones; but the immediacy of the image displayed here in the fortress site triggers a progression from romantic memory to its complete encasement by military concrete, encouraging visitors to mourn an elusive and obliterated past. At the same time, reinventing the Tomb as a fortress also legitimises the new settler-led cause that barricades them into a site of their own invention. Effectively, they are trapped by their own state of siege.

${ }^{14}$ Biblical and rabbinical passages are painted at the site on the mural of the Ottoman tomb: 'Restrain your voice from weeping and your eyes from tears, for there is reward for you accomplishment...your children will return home (Jeremiah 31.14-16); And G-D said: Rachel, for you I will return your children to their homeland' (Midrash Eicha Rabba) 
In attempting to attract visitors, the Committee for Rachel's Tomb states:

The trip to and from the Tomb is safe. The Israeli Border Patrol and Israel Defense Forces keep a continuous watchful eye over the entire area. The Tomb is within an enclave or compound that is surrounded by 20 foot high concrete walls for your protection. The Tomb has undergone massive exterior reinforcement and is a fortress in itself, yet the facade of the building has been tastefully and esthetically finished.

The aesthetic qualities are debatable, and as much as they are present, tend to fall in line with the severe brutalism of conflict infrastructures. There is little doubt that the combination of militarism and piety is effective, expressed in the orchestration of the site, in the timed entries of buses through the walled corridor, and the disgorging of visitors into a compound that has all of the fixtures of the frontier. Although not as splendid as the ceremonies at the Western Wall, there is an element of spectacle here, partly facilitated by the backdrop of huge military walls and towers. During Jewish festivals, thousands of people flood the site. And occasionally other groups enter into the heavy military choreography: on Orthodox Christmas, the steel gates at either end were opened and the Christian dignitaries of Bethlehem were escorted in a convoy of taxis by the Israeli army on their way to Jerusalem's Old City. ${ }^{15}$

${ }^{15}$ Observed Christmas Eve, 6.1.13. 
Some architecture is designed to instil both power and fear (Ellin, 1997, pp.1346; Virilio, 1986, pp.12-13, passim; Virilio, 2005). The militarised treatment of the Tomb enclosure purports to provide security, but the extreme qualities of the site and its architecture also convey anxiety in the very people it protects. The treatment of the compound immediately recalls the violent episodes that have plagued this site. Glimpses of Palestinian Bethlehem over the walls remind people to be afraid, and in doing so, such treatment helps to make a malleable audience. In the language that has become common to many, the Tomb is portrayed as an anti-terrorist outpost; Rachel's Tomb Committee (2005) calls it 'the fortress complex which is used to protect visitors from terrorists' (see also: Baranowski). With this sort of perception, Rachel's Tomb is no longer simply a militarised site for defence, but it becomes part of a wider militarism that is rooted in an all powerful threat that demands constant vigilance. Many small acts at the site reinforce this idea; one that particularly stands out: the wedding dress of a young woman who was killed in a terrorist attack in Jerusalem one day before her marriage was re-sewn and donated by her mother as a Torah curtain for Rachel's Tomb. ${ }^{16}$ Thus, while the fortress may be justified as protection to quell the fears of pilgrims, its unremitting militarism supports and even vindicates the settlers in their increasing domination of the Tomb.

But one major commemoration event has come to dominate the Tomb in recent years, reflecting radical changes in Israeli ideology. The anniversary of Rachel's death falls at about the same time as that of the assassinated Israeli

${ }^{16}$ This act was widely reported in the Jewish press after the 2003 suicide bombing and still resonates today (see for example: Ginsburg, 2013). 
Prime Minister Yitzhak Rabin. ${ }^{17}$ Religious-nationalists do not observe the annual remembrance for Rabin; feeling that they have been blamed for his murder ${ }^{18}$ they assert their rejection of the Tel Aviv ceremony by congregating instead at Rachels' Tomb (Newman, 2012). In 2012, approximately 20,000 people attended Rabin's memorial but 70,000 visitors were reported at Rachel's Tomb over a 24 hour period (Newman, 2012). Most religious nationalists particularly abhorred Rabin's championing of the Oslo Accords, which would have exchanged land for peace. As stated by the Rachel's Tomb Committee, they interpreted this to mean that the Prime Minister and his supporters made the agreement with the expectation of a 'secular-messianic era of peace' (Baranowski). Positing a state agreement in eschatological language not only regards the political secular in religious terms, it also thrusts the process into a new temporal framework based on eternity rather than history (Pullan et al, 2013). As such, it demonstrates the chasm between the two ways of thinking (Gorenberg, 2000; Sprinzak, 1991; Inbari, 2009).

The replacement of Rabin by Rachel offers further insights: in national religious terms, Rabin is seen as a false martyr and must be replaced by Rachel, who wept for her children and the nation and died in the violence of childbirth, and so became truly sacrificed. So powerful has the symbolism become that whenever a female settler has been murdered, Matriarch Rachel is invoked (Feige, 2009, p.227). As much as the swearing-in ceremonies at the Western Wall convey a powerful form of male dedication and impending bloodshed, the Tomb represents a long history of female devotion laced with

\footnotetext{
${ }^{17}$ Dates according to the Jewish calendar do not exactly correspond to the Gregorian calendar.

${ }^{18}$ The assassin came from the national religious movements.
} 
tragic episodes. The violence of the Tomb site - its isolation, its defences, its severe presence - heightens that sense of victimhood and necessary sacrifice already endorsed in memory of Mother Rachel.

\section{The Western Wall as site of sacrifice}

In Israel the 1967 conquest of the Western Wall is usually portrayed as the return of Judaism's holiest shrine to its national home, making the place itself symbolic of power and victory. In the tradition of Girard's (1977) important formulation of the interconnection and ambivalence of violence and sacrality, sacrifice can be seen to underlie this triumph and it is consistently present in both sacred history and current practice at the Wall. Two examples are worth relating here. The Binding of Isaac at Mount Moriah (Genesis 22.1-14) in Jewish belief is traditionally located at the Temple Mount and indicates Abraham's willingness to slaughter his son in deference to God's will. From this combination of faith and violence, Abraham's descendents are seen to form a blessed nation that in victory will 'possess the gate of their enemies' (Genesis 22.15-18). ${ }^{19}$ As at Rachel's tomb, this foundational narrative renders all of the nation's children from the same biblical sources and embeds them at that particular site (Feige, 2009, p.227).

In 1967 the national narrative once again demanded violent sacrifice at the Wall. This time it was captured in a photograph when a local cameraman called David Rubinger snapped three young paratroopers suddenly confronted with their own collective history at the ancient site of the Temple.

${ }^{19}$ In Islamic tradition a similar story is related, however Abraham's (Arabic: Ibrahim) son is not Isaac but Ismail, from whom Muslims are believed to have descended. 
Arriving in the midst of battle, the dazed and exhausted soldiers gaze heavenward in silent awe, each like a modern Isaac at Moriah saved from the slaughter, at least momentarily. The photo is an interlude, one that conveys the violence that immediately preceded it and was still to follow..$^{20}$ It was officially distributed by the Israeli Government Press Office and immediately became an icon of the war. The image is still regularly presented as a living myth; in the tourist shops of the Jewish Quarter posters of it are displayed next to romantic reprints of Eretz Israel from the 1920s, with the implication that the old dream of a nation has been realised by the events of 1967 (figure $11)$.

In many armies, sacrifice is lauded as a secular virtue that epitomises how the individual participates collectively to represent and secure the nation. But in some cases it may be more explicitly religious in reference and may be interpreted in fundamentalist terms (Denton-Borhaug, 2011). As far as Israel is concerned, sacrifice's roots in religion informs military language and ideology and the call for national security increasingly entails sacrifice and heroism based on religious motives (Furman, 1999, p..163). The sacrifice/security rationale justifies the underlying violence that characterises the defence of the nation. This is presented in the IDF swearing-ceremonies as a collective endeavour, one that, through its combination of both military and religious ideals, accommodates the various interpretations of collectivity. Although he refers to paramilitaries in Northern Ireland, Feldman's idea of sacrificial violence in the name of the collective works in a similar way,

${ }^{20}$ Rubinger claims to have arrived 15 minutes after the Wall was taken. He laid down on the pavement to catch the shot, hence the upward stare of the soldiers (Rubinger with Corman, 2007, p.123). 
providing it, the collective, with certain desired and controllable meanings. He states:

...sacrificial violence creates generic subjects as raw material vulnerable to labile objectification, for the process of sacrifice requires actors who can assume multiple collective meanings and absorb and reflect back diverse and often contradictory collective fantasies (2003, p.68).

To describe the collective understanding of the swearing-in ceremonies as 'fantasies' may be considered objectionable; nonetheless, it would be fair to say that, as at Rachel's Tomb, biblical narratives have accrued sufficient flexibility to be moulded to fit an impending situation or the aspirations of a particular segment of the population or an event. The Bible and gun ceremonies are emotional national events that offer a powerful venue for the absorption and reflection, and more recently, revision, of meaning. Perhaps one of the most explicit indications of this was in the choice of the swearing-in ceremony at the Wall to declare 'loyalty to God' above the IDF, as noted above (Press, 2010).

In the years since 1967, religious or quasi-religious experience in support of military action has been developed as a central part of visitors' centres established by the Western Wall Heritage Foundation ${ }^{21}$ in a series of underground caverns just north of the Wall. The Chain of Generations is a particularly explicit example. Through a dramatic rendering in sound and

${ }^{21}$ Originally a settler organisation now managed directly by the Prime Minister's office (Greenberg, 2009, p.274). 
light, the Center presents a history of the Jewish people 'from the time of the Patriarchs until the present' (Kotel). Elsewhere I have commented in detail on the staging of the underground chambers so that biblical history and revelation are manipulated to combine seamlessly with increasing militarisation in contemporary Israel (Pullan et al, 2013, ch.2). Here I wish to return only to two points in the organised tour: ${ }^{22}$ firstly, its culmination, in the presentation of the Paratrooper's Story of the 1967 taking of the Wall (Amirav). From his hospital bed, a wounded soldier relates the story of Rabbi Halevi, a victim of the Nazi genocide whose 'entire life was a song of yearning for Jerusalem' but was prevented from attaining it (Amirav). The soldier's own attachment to the Wall is realised in its capture and his own encounter with it as a wounded combatant in the middle of battle. He 'feels that he represents the Jewish people over the generations, and that Jews from previous generations are fighting alongside of him' (Amirav). In carrying on the practice of sacrifice, the soldier gives agency to those who had none, and ultimately the Wall becomes the sacrificial gift. At the end of the tour, immediately after this story, the visitors are spewed out of the Center to confront the Wall themselves. The second point I wish to draw on takes place a little earlier in the visit. In the 'State of Israel' chamber visitors are told that they must stand together to build a country that is not yet finished; the assumption seems to be that everyone on the tour is Jewish or else supports Israel. Whether future nation building means further territorial expansion is not stated, but the allusion to the threat of ongoing wars and future hostilities is very clear indeed. In other words, future sacrificial acts will be required.

${ }_{22}$ Visited 30.5.11, 17.1.13. Admission is possible only on an organised tour. 


\section{Conclusion: Violence and the urban topography}

In both the locations considered in this study, violence dominates primary religious traditions and quasi religious myths. These meanings are well embedded in the physical sites, and although they are largely based in collective memories or histories, there is a strong sense of further violence to be experienced in the future. Modern military intervention is reinforced by the potency of the sites, and reciprocally, the military content offers the holy places continuing legitimacy and endurance in a secularised world. The hermeneutic circle is completed by the role of sacrifice that emerges from both religious beliefs and military expectations and their exigencies. Sacrifice reinforces the collective, which is demanded of both religion and the military, and in the name of the nation, it is regarded as the justification for violence.

At the sites, various structures and mechanisms arise from popular tradition or are purposefully used. Victimisation is incorporated to reinforce the virtues of sacrifice. An architecture combining both defence and fear enhances the victimisation scenario to reinforce the need for sacrifice. Varying use of spectacle and drama adds to the emotional values of the sites and this helps to convey the need for the collective and for sacrifice. The sites are commanding and well-controlled by both military and religious authorities but at the same time they also have a fluidity that, within certain boundaries, accommodates changing relationships of nation and religion. What continues to unite both sites in the ways that they are understood and used is a broad-brush threat of war, and even more so, of terrorism. It is a fear that affects both secular and religious Israelis and is absorbed into collective memories and experience that 
exist deep within the Western Wall and Rachel's Tomb. But the presentation of the threat allows virtually no engagement with the present realities of the occupation, even though the Palestinians go about their daily lives just beyond the borders of the two sites.

Rachel's Tomb and the Western Wall represent very different parts of Jerusalem. One is a fortress at the periphery of the city, embodying the radical conditions of that frontier. The population that uses it reflects its extreme position in their own political and religious beliefs. The Western Wall, on the other hand, is in the centre of the historic quarter of Jerusalem, on a wellrecognised and venerable site that represents the nation. It attracts a broad cross-section of the population, including secular Israelis. To some extent it is possible to say that the two sites act in tandem with the overall spatial structure of the city, being formed by the urban centre and periphery and underpinning these qualities by their own differing characteristics. But what they reinforce is an embattled city, and neither aid in developing its viability for all of its inhabitants. Furthermore, each site exhibits a worrying qualification that emerges out of its own capacity for exclusivity and incorporation of heavy violence. On the far edge of the city, Rachel's Tomb has a marginal status today. However, we appear to be witnessing a site that is being groomed by national religious interests in order to enhance its significance in the national pantheon of holy places. At the moment its beleaguered status and harsh demeanour suit this aim; its place on the frontier emphasises the settlers' struggle. However, the settlers' goals are long term: today the Tomb exists only because of the protection of the IDF; in future the settlers wish and expect it to become part of a wider West Bank 
strategy that will integrate Rachel's Tomb into a more extensive area of Jewish settlement. Rachel's Tomb Committee (Baranowski) states: 'new threats will always on the horizon until the government gives the word and for the IDF to retake Bethlehem forever. Until that time, Rachel's Tomb will be at risk'. No longer an extreme frontier, they see it in a more central urban position. This does not bode well for indigenous rights in this overwhelmingly Palestinian territory.

The military ceremonies at the Western Wall are well-accepted among most Israelis in what is regarded as a well-defined compound next to the Jewish Quarter. But here as well, much of the Old City is Palestinian, and settlers are hard at work in appropriating property in the Christian and Muslim Quarters. Much of this is very acrimonious and leads to regular clashes. Militarisation is certainly not restricted to the Western Wall Plaza, and with increasing national religious representation in the IDF there are greater numbers of soldiers that support settler aims. At the instigation of the settler organisation Ateret Cohanim, paratrooper groups now march in the Old City, particularly focusing on the Muslim Quarter (Zitun, 2012). Besides being highly provocative in themselves, the memories of the city's capture in 1967 are easily re-enacted in these marches. They have been transferred from a symbolic ceremony in the Western Wall Plaza to intrude deeply into Palestinian neighbourhoods. The mimetic quality adds to what is already divisive, and increases the build-up of a frontier in the centre of the most historic quarters of Jerusalem. The combination of military zeal and religious radicalisation in the centre of Jerusalem make it particularly dangerous, even more so than at the periphery (Pullan, 2011). 


\section{References}

Amirav, M. A Paratrooper's Story, The Generations Center, The Western Wall Heritage Foundation, http: / / english.thekotel.org/ content.asp?Id=229

Barak, O. and G. Sheffer (2010) The Study of Civil-Military Relations in Israel: A New Perspective, in G. Sheffer and O. Barak (Eds.) Militarism and Israeli Society. Bloomington, IN : Indiana University Press, pp.14-41.

Baranowski, D. And the War Continues. Overview and Comment, Rachel's Tomb Committee, http://www.rachelstomb.org/update.html

Ben-Eliezer, U. (1998) The making of Israeli militarism. Bloomington : Indiana University Press.

Ben-Yehuda, N. (1995) The Masada Myth. Collective Memory and Mythmaking in Israel. Madison, Wisconsin: University of Wisconsin Press.

Benn, A. (2009) Settlers are addicted to government money, Haaretz, 30.12.09, http:/ / www.haaretz.com/print-edition/opinion/settlers-are-addicted-togovernment-money-1.1118

Benn, A. (2013) Israel's media censorship of the Prisoner X story is a sad fact of life, The Guardian,15.2.13, www.guardian.co.uk/commentisfree/2013/feb/15/israel-censorshipprisoner-x.

Cohen, S.A. (2000) The Scroll or the Sword? Tensions between Judaism and Military Service in Israel, in S. A. Cohen (Ed.) Democratic Services and their Armed Forces. Israel in Comparative Context. London and Portland OR: Frank Cass, pp. 254-73.

Cohen, S.A. (2007) The Re-Discovery of Orthodox Jewish Laws Relating to the Military and War (Hilkhot Tzavah U-Milchamah ) in Contemporary Israel: Trends and Implications, Israel Studies, 12(2), pp.1-28.

Cohen, S.A. (2008) Israel and its Army. From cohesion to confusion. London and New York: Routledge.

Conflict in Cities interviews (2011). Dress rehearsal and swearing-in ceremony of the anti-aircraft training base of the IDF Air Force, Western Wall, Jerusalem, 30.5.11.

Cust, L.G.A. (1980) The Status Quo in the Holy Places. Jerusalem: Ariel, facsimile edition of 1929 publication.

Denton-Borhaug, K. (2011) US War-culture, Sacrifice and Salvation. Sheffield and Oakville: Equinox. 
Dumper, M. (2013) Policing divided cities: stabilization and law enforcement in Palestinian East Jerusalem, International Affairs 89(5), pp.1247-1264.

Eggen Røislien, H. (2013) Religion and Military Conscription: The Case of the Israel Defense Forces (IDF), Armed Forces E Society, 39(2), pp.213-32.

Ellin, N. (1997) Shelter from the Storm or Form Follows Fear and Vice Versa, in N. Ellin (Ed.) Architecture of Fear. New York: Princeton Architectural Press, pp.13-46.

Emek Shaveh: Archaeology in the shadow of the conflict, http: / www.altarch.org

Feige, M. (2009) Settling in the Hearts. Jewish Fundamentalism in the Occupied Territories. Detroit: Wayne State University Press.

Feldman, A. (2003) Political Terror and the Technologies of Memory: Excuse, Sacrifice, Commodification, and Actuarial Moralities, Radical History Review, 85(1), pp. 58-73.

Furman, M. (1999) Army and War: Collective Narratives of Early Childhood in Contemporary Israel, in E. Lomsky Feder and E. Ben-Ari (Eds.) The Military and Militarism in Israeli Society. Albany: State University of New York Press, pp.141-68.

Ginsburg, M. (2013) On Obama's path to Bethlehem, a harshly fortified shrine, Times of Israel, 22.3.13, http:/ / www.timesofisrael.com/on-obamaspath-to-bethlehem-a-harshly-fortified-shrine /

Girard, R. (1977) Violence and the Sacred, (Trans.) Patrick Gregory. Baltimore: Johns Hopkins University Press, reprinted 1993.

Gorenberg, G. (2000) The End of Days: Fundamentalism and the Struggle for the Temple Mount. Oxford: Oxford University Press.

Greenberg, R. (2009) Extreme Exposure: Archaeology in Jerusalem, Conservation and Management of Archaeological Sites, 11(3-4), pp.262-81.

Haaretz Editorial (2013) The emergence of Israel's settler government, Haaretz, 19.3.13,

http: / / www.haaretz.com/ opinion/the-emergence-of-israel-s-settlergovernment.premium-1.510338?block=true

Hassner, R.E. (2009) War on Sacred Grounds. Ithaca and London: Cornell University Press.

Horowitz, D. and Lissak, M. (1989) Trouble in Utopia : the overburdened polity of Israel. Albany : State University of New York Press.

Inbari, M. (2009) Jewish Fundamentalism and the Temple Mount. Who will build the Third Temple? Albany: State University of New York Press. 
Institute of National Security Studies (2011) chapter: 'Israel', 11, updated 2012, http: / / cdn.www.inss.org.il.reblazecdn.net/upload/(FILE)1336472780.pdf

Kimmerling, B. (1993) Patterns of Militarism in Israel, European Journal of Sociology, 34(2) , pp. 196-223.

Kimmerling, B. (1999) Religion, Nationalism and Democracy' in Israel, Constellations, 6(3), pp. 339-56.

Kotel-Western Wall Heritage Foundation, http: / / english.thekotel.org/ content.asp? Id=228;

Lomsky Feder, E. and E. Ben-Ari (Eds.) (1999) The Military and Militarism in Israeli Society, (Albany: State University of New York Press, 1999)

Lutz, C. (2002) Making War at Home in the United States: Militarization and the Current Crisis, American Anthropologist, New Series, 104(3), pp. 723-735.

Mayer, T. (2008) Jerusalem In and Out of Focus: The City in Zionist Ideology, in T. Mayer and S. A. Mourad (Eds.) Jerusalem: Idea and Reality. London and New York: Routledge, pp.224-44.

Nachshoni, K. (2013) Jerusalem: Haredim attack Women of the Wall, Ynet, 10.5.13, http: / / www.ynetnews.com/articles / 0,7340,L-4378516,00.html

Newman, D. (2012) Borderline Views: Mother Rachel and Father Rabin, Jerusalem Post, 29.10.12,

http: / / www.jpost.com/Opinion/Columnists / Borderline-Views-MotherRachel-and-Father-Rabin

Press, E. (2010) Israel's Holy Warriors, NY Review of Books, 29.4.10, http: / / www.nybooks.com/articles/archives/2010/apr/29/israels-holywarriors/?pagination=falsehttp: / / www.nybooks.com/articles/archives / 201 $\underline{0 / \text { apr } / 29 / \text { israels-holy-warriors } / \text { ?pagination=false }}$

Pullan, W. (2011) Frontier urbanism: The periphery at the centre of contested cities, The Journal of Architecture, 16(1), pp.15-35.

Pullan, W. (2013a) Conflict's Tools. Borders, boundaries and mobility in Jerusalem's spatial structures, Mobilities 8(1), pp.125-47.

Pullan, W. (2013b) Strategic Confusion: Icons and infrastructures of conflict in Israel-Palestine, in Interventions in the political geographies of walls, K. Till (Ed.) Political Geography, 33, pp. 55-58.

Pullan, W., M. Sternberg, L. Kyriacou, C. Larkin, M. Dumper (2013) The Struggle for Jerusalem's Holy Places. London and New York: Routledge.

Rachel's Tomb Institute, http: / / www.keverrachel.com/ content.asp?lang=en\&pageid=17

Rachel's Tomb Committee, http:/ / www.rachelstomb.org. 
Rachel's Tomb Committee (2005) Pictures from the Yahrzeit - Anniversary of the Death - of our Matriarch Rachel, 5766 (November, 2005 C.E.), http://www.rachelstomb.org/yahrzeil_pictures_2005.html.

Rubinger, D. with R. Corman (2007) Israel Through My Lens. New York and London: Abbeville.

Saragusti, A. (2013) Post-Election Gender Roadmap for the Israeli Knesset, Heinrich Böll Foundation, 5.6.13, http: / / www.il.boell.org/ web/96-497.html.

Sela, N. (2007) Rabbi Shapira forbids visiting Temple Mount, Ynet, 16.5.07, www.ynetnews.com/articles/0,7340,L-3400750,00.html

Selwyn, T. (2009) Ghettoizing a matriarch and a city: An everyday story from the Palestinian/Israeli borderlands, Journal of Borderlands Studies, 24(3), pp.3955.

Semmerling, T.J. (2004) Israeli and Palestinian Postcards. Presentations of National Self. Austin: University of Texas Press.

Sheffer, G. and O. Barak (Eds.) (2010) Militarism and Israeli Society.

Bloomington, IN : Indiana University Press.

Strickert, F. (2007) Rachel Weeping: Jews, Christians and Muslims at the Fortress Tomb. Collegeville, Minnesota: Liturgical Press.

Virilio, P. (1986) Speed E Politics. M. Polizzotti (Trans.) New York: Semiotext(e).

Virilio, P. (2005) City of Panic. J. Rose (Trans.) Oxford and New York: Berg.

Weizman, E. (2007) Hollow Land. Israel's Architecture of Occupation. London and New York: Verso.

Western Wall Heritage Foundation, http: / / english.thekotel.org/today/article.asp?ArticleID=157.

Zertal, I. and A. Eldar, (2007) Lords of the Land. The War Over Israel's Settlements in the Occupied Territories, 1967-2007. V. Eden (Trans.) New York: Nation Books.

Zitun, Y. (2012) IDF says paratroopers' march through Muslim Quarter a 'provocation', Ynet, 1.12.12; http: / / www.ynetnews.com/articles /0,7340,L4175036,00.html 
